\title{
The twelve blooms of Christmas
}

\author{
Plant blindness is a pernicious force, even affecting the coming festive season. How can we increase the plant- \\ based content of a well-known list of Christmas gifts?
}

n n the well-known Christmas carol, the final tally of gifts the singer's beloved sends on the 12 days following Christmas is eye-watering, including 56 geese and swans, 30 hens and a pipe-and-drum band of some 34 players. At Nature Plants, we prefer something a little more botanical some suitable plants to replace the carol's traditional gifts with recently published research to go along with them.

As a replacement for 'drummers drumming, there is a variety of allium called 'Summer Drummer', whose purple and white flowers are borne on upright stems through spring and summer. It should be no great surprise that there has been no research done on this particular variety of plant in 2019, but there have been quite a few studies on the complicated phylogeny of alliums in general. For example, researchers at Shandong Agricultural University, have demonstrated the use of chloroplasts genomes to reconstruct the evolution of the genus ${ }^{1}$.

Eleven 'pipers piping' can be replaced by the entire genus Piper of the Piperaceae, including the spice plant pepper (Piper nigrum). In their native environment, Piper species are tropical shrubs with a formidable array of phytochemicals for use in defence. The precise makeup of such phytochemicals is affected by the vertical position of the bushes ${ }^{2}$. Plants higher up in the canopy have a greater diversity of secondary metabolites, possibly due to interactions between photoactive and nonphotoactive synthetic pathways.

It always seems a shame that the leaping lords and dancing ladies are kept apart when they could be enjoying each other's company. So our next botanical gift would be 'lords-and-ladies', Arum maculatum. 'Lords-and-ladies' is only one of the many names for this common European wild flower - some people will know it as 'cuckoo-pint' or 'friar's cowl', or even 'jack-in-the-pulpit'. The diversity of names is matched by the diversity of medicinal uses to which its extracts have been put. It is comforting to know that randomized clinical trials have shown it to be an effective treatment for haemorrhoids ${ }^{3}$.

'Red-maids', formally known as Calandrinia ciliate, is a native of western north America, bearing deep pink or red flowers. However, in Australia, there are over 70 species of Calandrinia which have spread to occupy most ecosystems. Many Calandrinia species can employ Crassulacean acid metabolism (CAM) in response to periods of drought. Despite this ability to facultatively turn on CAM, none of the Calandrinia species have developed a strong CAM phenotype ${ }^{4}$. Perhaps an annual life history is incompatible with strong CAM photosynthesis?

From here on, our carol's list becomes highly ornithological, with birds being given for six of the next seven gifts. Sadly, there are no 'birds of paradise' on our lover's shopping list. Instead, we look to the swan plant, Gomphocarpus physocarpus. 'Swan plant' is one of its politer names. This plant's distinctive, spherical seed-bearing organs mean that it is also known as the 'balloonplant', 'hairy balls' or even 'bishop's balls' Let's move on quickly, just pausing to note that the swan plant forms part of the ethnopharmacopeia of Mauritius ${ }^{5}$.

For geese, there is the 'yellow snowdrop' or 'goose onion' Gagea lutea. This is a member of the Liliacae family, with a wide geographic distribution and beautiful yellow flowers in early spring. Looking at the ribosome and chloroplast DNA of 116 species of the genus Gagea has shown that the group originated in southwestern Asia, where it began its diversification in the early Miocene ${ }^{6}$.

'Golden ring' is a horticultural variety of the Japanese barberry, Berberis thunbergii. $B$. thunbergii can be a problematic invasive species, suppressing and replacing native trees and shrubs in temperate woodland, especially in North America. However, management of this invasive alien may not require its complete removal. Native species can be successfully reintroduced into invaded areas by thinning alone ${ }^{7}$.

For 'colly birds', read 'cauliflowers' and the wealth of research on Brassica oleracea (once you have discarded all the material science papers relating to 'cauliflower-like nickel hydroxide particles', which apparently have a number of useful applications, including batteries and solar panels). From the around 160 research papers involving $B$. oleracea, one used the pangenome of the species to identify potential new resistance genes, initially identifying 1,989 candidates that were whittled down to 59 promising leads for Brassica breeders ${ }^{8}$.

Hens, French or otherwise, can be the 'hens and chicks plant', Sempervivum tectorum, a succulent perennial member of the Crassulaceae, which produces a liquid with wound healing properties ${ }^{9}$. Meanwhile, the dove-tree, Davidia involucrate, might prove to be the most welcome of all our botanical gifts. This is a relic species that, like Ginkgo biloba, seems little changed from its fossil ancestors. The inflorescences of $D$. involucrate have prominent white bracts, which remind some people of white birds, but others of ghosts or pockethandkerchiefs. Hopefully a transcriptome analysis of $D$. involucrate's response to heat ${ }^{10}$ will be a step towards protecting this coolclimate-adapted species from climate change threats.

Pear trees and partridges are only ever seen together in our Christmas carol; this grassland game bird does not stray into pear orchards. But if pears don't shelter partridges, perhaps they themselves can benefit from the protection of other plants. That is exactly the focus of a study investigating strategies to increase populations of the endangered Iberian pear, Pyrus bourgaeana, into the Doñana Biosphere Reserve ${ }^{11}$. Whether growing seedlings under other, more mature plants would increase their success is complicated, confounded by the provenance of the pear seedlings and the exact characteristics of restoration sites.

That completes this updated $12(\mathrm{OK}, 11)$ gifts. More convenient than the true love's alleged offerings, but more problematical to make rhyme and scan.

Published online: 9 December 2019 https://doi.org/10.1038/s41477-019-0574-X

\footnotetext{
References

1. Huo, Y. M. et al. Sci. Rep. 9, 12250 (2019).

2. Glassmire, A. E. et al. Ecol. Lett. 22, 332-341 (2019).

3. Zisis, S. et al. J. Appl. Pharm. Sci. 9, 40-45 (2019).

4. Hancock, L. P. et al. Integr. Comp. Biol. 59, 517-534 (2019).

5. Suroowan, S. et al. S. Afr. J. Bot. 122, 189-213 (2019).

6. Peterson, A. et al. Ecol. Evol. 9, 5870-5890 (2019).

7. Link, A. F. et al. Plant Ecol. 220, 577-593 (2019).

8. Bayer, P. E. et al. Plant Biotech. J. 17, 789-800 (2019).

9. Cattaneo, F. et al. Phytochem. Analysis 30, 524-534 (2019).

10. Liu, Q. et al. Forests 10, 656 (2019).

11. Fedriani, J. M. et al. J. Appl. Ecol. 56, 996-1006 (2019).
} 